\title{
The benefits and dangers for churches and ministry institutions to work in a regulated environment, with reference to professionalising religious practice via South African Qualifications Authority and the National Qualifications Framework Act
}

Author:

Graham A. Duncan ${ }^{1}$ (D)

Affiliation:

${ }^{1}$ Department of Church History and Church Polity, Faculty of Theology and Religion, University of Pretoria, South Africa

Research Project Details: Project Leader: G.A. Duncan Project Number: 02618958

Project Description: This research is part of the research project, 'History of Theological Education in Africa' directed by Prof. Dr Graham Duncan of the Department of Church History and Church Polity at the Faculty of Theology, University of Pretoria.

Corresponding author: Graham Duncan, graham.duncan@up.ac.za

Dates:

Received: 03 Sept. 2017

Accepted: 18 Mar. 2018

Published: 26 July 2018

How to cite this article: Duncan, G.A., 2018, 'The benefits and dangers for churches and ministry institutions to work in a regulated environment, with reference to professionalising religious practice via South African Qualifications Authority and the National Qualifications Framework Act', HTS Teologiese Studies/Theological Studies 74(4), 4802. https://doi. org/10.4102/hts.v74i4.4802

Read online:
Since 1994 and the coming of democracy to South Africa there has been a concerted attempt to develop a coherent, unified educational system that will redress the inequities of the apartheid systems. Significant to this ongoing process is the field of higher education, where relevant legislation has been enacted in order to bring coherence and consistency to the education system in the public and private sectors. Significant issues have arisen with regard to the provision made by private religious educational institutions, especially those who have experienced difficulties in being accredited by statutory bodies. This paper seeks to explore these issues and suggest ways forward that are appropriate within an emerging unitary system of education that is fit for purpose in Africa and particularly South Africa, taking as a case study the formation of the Association of Christian Religious Practitioners.

\section{Introduction}

Recently, the Association of Christian Religious Practitioners (ACRP) was established after a lengthy struggle by a number of institutions and interested parties to conform to South African legislation relating to the registration of church-related bodies on behalf of practitioners who, for various historical, social, economic and political reasons, had been unable to acquire relevant accredited training for their members in order to carry out the tasks and roles that were assigned to them in churches and church-related bodies. Two bodies merged to form the ACRP: the Association for Ministry Training Practitioners and the South African Association for Pastoral Work. The Higher Education Qualifications Sub-framework (2013) strictly defines the qualifications from National Qualifications Framework (NQF) level 5 (Higher Certificate) but does not specify in any detail the requirements of NQF levels 1-4 (General, Elementary, Intermediate and National certificates), which do not refer to higher education levels. However, these are the optimum levels at which many Christian religious practitioners are able to operate comfortably. The main higher education providers affected by these issues are private institutions, which constitute a significant part of the theological education 'market' at the lower NQF levels, and they struggle with many issues that the public institutions avoid through their access to greater resources. This paper seeks to understand the issues that affect those who wish to operate within the regulatory framework.

\section{Professionalisation}

The term 'profession' is problematic when related to any religious activity. When the professions of law, medicine and theology were established as the prime activities of medieval universities they were in fact viewed as means of professing specific skills within interdependent vocations. Hence, I prefer the term 'vocation', although I do believe strongly that we need to adhere to professional standards and values in whatever activities we engage. Yet I do not find these to be significantly different within a faith context. Professionalism does not offer us any more than vocation in terms of criteria values and character. Professionalisation skills in word and action are transforming. My prime markers, all of which have many subheadings, are justice, peace and the integrity of creation these are human (read Christian à la Hans Küng 1978:602) values. These values lie behind the legislation that has been enacted since 1994 with the aim of developing and promoting a fair, just and unitary system of education within a nation wherein education and all other key aspects of life

Copyright: ( 2018. The Authors. Licensee: AOSIS. This work is licensed under the Creative Commons Attribution License. 
had been strictly regulated on a racial basis. This has been developed within a national context that is both uncertain and complex. Here, the expression used will be professional[isation], as this is the term found in documentation.

All our efforts in this regard need to be guided by sound professional educational and academic principles. These include the following:

- adopting a student-centred approach by relating teaching to learning in order to determine appropriate course design and design of learning opportunities; respecting diversity and accommodating a variety of learning styles and strategies

- ensuring coherence of the components of instruction: learning outcomes, assessment criteria, feedback and instructional design

- extending and deepening knowledge by articulating and clarifying expectations relating to learning objectives in terms of knowledge, skills and attitudes, and encouraging critical and reflective thinking

- prioritising what we teach, when and how on the understanding that we cannot teach everything, yet we can inculcate applicable methods

- inviting engagement and providing appropriate learning support by providing appropriate learning support by integrating a variety of teaching methods to support facilitation of student learning

- transforming views and inspiring change by progressively developing and refining our courses based on reflection and feedback (adapted from Eberly Center 2015; Grové 2006).

I am also guided by the integrity of the gospel. This is not to suggest that others are not, but this is where I come from. I am employed in a public higher education institution and I also work for the Council on Higher Education (CHE) and the National Research Foundation, whose work I both admire and support, though not uncritically, in their attempt to operate with the values of fairness, validity and reliability (Government Gazette R 1127, 5.18.b) in setting the standards for qualifications. Added to this are matters relating to access and mobility (Government Gazette R 1127, 2.3.2.h) and accountability and transparency (Government Gazette $\mathrm{R}$ 1127 3.10.2). Yet what follows is informed by my experience gained in the South African educational domain.

Everything that follows has to be seen in the light of the significant work of the Commission for the Promotion and Protection of the Rights of Cultural, Religious and Linguistic Communities, which is an independent chapter nine institution in South Africa. It draws its mandate from the South African Constitution by way of the Commission for the Promotion and Protection of the Rights of Cultural, Religious and Linguistic Communities Act of 2002 (CRL 2017). The key phrase here relates to both the promotion and protection of persons, particularly vulnerable persons in religious and other communities, who are at risk at the hands of unscrupulous care providers who are not worthy of the great trust placed in them. The prime focus on religious organisations is selfregulation rather than state regulation, while at the same time acting against those who bring religion into disrepute.

The two key documents that are of concern to us here are the National Qualifications Framework, Act 67 (2009), and the South African Qualifications Authority (SAQA) Act (1995). These form part of the cohort of legislation that constitute the framework of education in South Africa in a democratic society. They both relate to the higher education sector and are both based in the need to promote access, mobility and success for learners. In addition, we take into account two documents from the ACRP (NPC Reg No 2015/319357/08): its Memorandum of Incorporation and its Rules Document.

\section{Taking account of the relevant statutes}

What follows is a commentary on the relevant legislation affecting the processes involved in formation of the ACRP. The SAQA Act provides for the development and implementation of an NQF by creating one national framework of learning achievements, providing access to mobile, progressive career opportunities, improving the quality of education and training, driving the process of redress of former unfair discrimination and enhancing the individual's and the nation's ability to fulfil its potential.

The purpose of SAQA is 'monitoring and auditing achievements in terms of national standards or qualifications' (2.1) through comprehensive quality assurance mechanisms that are both transparent and accountable. This seeks to provide qualifications that meet nationally agreed skills standards and are transferable and mobile within a system that takes account of its segregated history of educational provision. The NQF Act (2008) is a natural outcome of the SAQA Act.

Regulations under the South African Qualifications Authority Act, 1995 (ACT NO. 58 OF 1995)

\section{Accreditation:}

is 'for the purpose of monitoring and auditing achievements in terms of national standards or qualifications' (2.1).

Criteria for accreditation of Education and Training Quality Assurance Bodies

... it has a primary focus for its quality assurance activities based upon its association with the identified sector and the identified mission of that sector; ...

1. quality management policies which define the quality which the Education and Training Quality Assurance Body wishes to achieve;

2. quality management procedures which enable the Education and Training Quality Assurance Body to practice its defined quality management policies; and

3. review mechanisms which ensure that the quality management policies and procedures defined are applied and remain effective;

in respect of the quality assurance function, it has national stakeholder representation at decision-making level, which 
representation shall ensure public accountability and transparency (3.1.b, d, e, f, h, i)...

Functions of Education and Training Quality Assurance Bodies

1. An Education and Training Quality Assurance Body shall -

a. accredit constituent providers for specific standards or qualifications registered on the National Qualifications Framework;

b. promote quality amongst constituent providers;

c. monitor provision by constituent providers;

d. evaluate assessment and facilitation of moderation among constituent providers;

e. register constituent assessors for specified registered standards or qualifications in terms of the criteria established for this purpose;

f. take responsibility for the certification of constituent learners;

Criteria for accreditation of providers

(i) quality management policies which define that which the provider wishes to achieve;

(ii) quality management procedures which enable the provider to practise its defined quality management policies; or

(iii) review mechanisms which ensure that the quality management policies and procedures defined are applied and remain effective; (13.a,b)

is able to develop, deliver and evaluate learning programmes which culminate in specified registered standards or qualifications. (13.c)

The NQF is a nationally recognised system for the classification, registration, publication and articulation of quality-assured national qualifications. Its provisions are similar to those of the $S A Q A$ Act.

\section{No. 67 of 2008: National Qualifications Framework Act, 2008}

\section{PREAMBLE}

WHEREAS the advancement and recognition of learning is an essential attribute of a free and democratic nation and a prerequisite for the development and well-being of its citizens;

WHEREAS the National Qualifications Framework has been developed and implemented in terms of the South African Qualifications Act, 1995;

WHEREAS the National Qualifications Framework has won wide acceptance as the principal instrument through which national education and training qualifications are recognised and quality-assured; and

WHEREAS a review of the implementation of the National Qualifications Framework has necessitated changes to the governance and organisation of the framework so that its objectives may be more effectively and efficiently realised....

Object of Act:

2. The object of this Act is to provide for the further development, organisation and governance of the NQF.

This indicates that the process is dynamic, being both developmental and participatory. The self-regulatory nature of higher education, as propagated by the CHE's Higher Education Quality Committee (HEQC), should be taken as an opportunity to be involved in the processes provided by the regulatory bodies.

\section{CHAPTER 2}

\section{NATIONAL QUALIFICATIONS FRAMEWORK}

Framework

4. The NQF is a comprehensive system approved by the Minister for the classification, registration, publication and articulation of quality-assured national qualifications.

The framework seeks to provide a comprehensive cohort of programmes having national, and also international, recognition.

\section{Objectives of NQF:}

\section{1. The objectives of the NQF are to:}

a. create a single integrated national framework for learning achievements;

b. facilitate access to, and mobility and progression within, education, training and career paths;

c. enhance the quality of education and training;

d. accelerate the redress of past unfair discrimination in education, training and employment opportunities.

5.2. The objectives of the NQF are designed to contribute to the full personal development of each learner and the social and economic development of the nation at large.

5.3. SAQA and the QCs must seek to achieve the objectives of the NQF by:

a. developing, fostering and maintaining an integrated and transparent national framework for the recognition of learning achievements;

b. ensuring that South African qualifications meet appropriate criteria, determined by the Minister as contemplated in section 8 , and are internationally comparable; and

c. ensuring that South African qualifications are of an acceptable quality.

The emphasis is on a 'single integrated' system characterised by access and mobility, in contradistinction to the static and stunted 'hewers of wood and drawers of water' (Joshua 9:21) apartheid model. It aims both to promote the needs of individuals as well as to meet the needs of the community, both national and international.

\section{Objects of SAQA}

11. The objects of the SAQA are to:

a. advance the objectives of the NQF contemplated in Chapter 2;

b. oversee the further development and implementation of the NQF; and

c. co-ordinate the sub-frameworks....

Functions of SAQA

13. (1) The SAQA must, in order to advance the objectives of the $\mathrm{NQF}-\ldots$

(i) with respect to professional bodies - ...

(i) develop and implement policy and criteria for recognising a professional body and registering a professional designation for the purposes of this Act, after consultation with statutory 
and nonstatutory bodies of expert practitioners in occupational fields and with the QCs [quality councils]; and

(ii) recognise a professional body and register its professional designation if the criteria contemplated in subparagraph (i) have been met; ...

(j) with respect to international relations -

(i) collaborate with its international counterparts on all matters of mutual interest concerning qualifications frameworks; and

(ii) inform the QCs and other interested parties about international practice in the development and management of qualifications frameworks; ...

(k) with respect to research -

(i) conduct or commission investigations on issues of importance to the development and implementation of the NQF, including periodic studies of the impact of the NQF on South African education, training and employment; and

(ii) publish the findings of the investigations referred to in subparagraph (n) with respect to other matters -

(i) inform the public about the NQF ...

This provides the link between statutory and professional bodies. This consultative provision is vital to promote state policy and professional integrity. Again, we note the desire to meet and promote international standards of achievements. The transparency of the exercise is derived from publication of research findings.

\section{CHAPTER 6 PROFESSIONAL BODIES}

\section{Co-operation with QCs}

28. Despite the provisions of any other Act, a professional body must co-operate with the relevant $Q C s$ in respect of qualifications and quality assurance in its occupational field.

\section{Recognition by SAQA}

29. A statutory or non-statutory body of expert practitioners in an occupational field must apply in the manner prescribed by the SAQA in terms of section 13(1)(i)(i) to be recognised as a professional body in terms of this Act.

\section{Registration of professional designation}

30. A professional body that is recognised in terms of section 29 must apply to the SAQA, in the manner determined by the SAQA in terms of section 13(1)(i)(ii), to register a professional designation on the NQF.

\section{Information}

31. A professional body must, in consultation with the SAQA:

a. maintain a database for the purposes of this Act;

b. submit such data in a format determined in consultation with the SAQA for recording on the national learners' records database contemplated in section 13(1)(l).

The key to this section is consultation and co-operation between the different professional groups and quality councils. Government does not establish professional councils; these emerge from within specific groups.

Previously, in theological education, this monitoring function was provided for through the expertise of the Joint Board for the award of the Diploma in Theology.

\section{Joint Board for the Diploma in Theology}

Prior to the introduction of a new dispensation in education in a democratic South Africa, the only accrediting body in South Africa was the Joint Board for the award of the Diploma in Theology:

In 1965, participating churches (Anglican, Methodist, Congregational Church) together established the Joint Board for the Diploma in Theology set up by the South African Council for Theological Education (SACTE) which included representation from across mainline denominations in Southern Africa. Established in order to provide an ecumenically recognised and peer reviewed qualification, it became the chief accrediting body until the new South African educational legislation. A common diploma was awarded to students of colleges that operated under the Joint Board, with quality assurance being provided by the Board in addition to a sharing of expertise and resources. (Naidoo 2015b:69, n. 15)

Each of the 19 seminaries accredited with the Joint Board had to apply anew for accreditation, an expensive and technical exercise that many found difficult (Naidoo 2015b:169). They met biannually to verify and standardise marks for their modules taught and assessed, and to discuss relevant common issues related to their work. This was a quality assurance body. The ACRP has the potential to perform similar functions to the Joint Board.

\section{The Association of Christian Religious Practitioners}

The context of the formation of the ACRP is the existence of a deep need for pastoral care within Christian contexts and therefore for professional training to provide for this particular form of vocation. Many caregivers do not have intellectual qualifications, yet they possess skills that need to be refined and directed in this critical field of care. This need has highlighted an important element in theological education, which is its universal nature: 'Theological education is for the whole people of God' (Amanze 2010:111), not only highly trained 'experts', which also implies 'ordained'. Njoroge (2008:64) affirms the role of the church as the people of God to perform healing and caring functions in a broken world. This has good historical foundations in the Bible and in the Protestant Reformation's 'priesthood of all believers' principle, now supported by the Roman Catholic Church's concept of 'the people of God':

You also, as living stones, are being built up a spiritual house, a holy priesthood, to offer up spiritual sacrifices acceptable to God through Jesus Christ ... But you are a chosen generation, a royal priesthood, a holy nation, His own special people, that you may proclaim the praises of Him who called you out of darkness into His marvellous light. (1 Pt 2:5-9)

This was confirmed by Luther (1520):

As St. Paul says (1 Cor. xii.), we are all one body, though each member does its own work, to serve the others. This is because we have one baptism, one Gospel, one faith, and are all Christians 
alike; for baptism, Gospel, and faith, these alone make spiritual and Christian people. (p. 2)

It was further confirmed by Vatican II (Lumen gentium $\$ 10$, Flannery 1975):

The baptized, by regeneration and the anointing of the Holy Spirit, are consecrated to be a spiritual house and a holy priesthood, that through all the works of Christian men [sic] they may offer spiritual sacrifices and proclaim the perfection of him who has called them out of darkness into his marvellous light (cf. 1 Pet 2:4-10). Therefore, all the disciples of Christ, persevering in prayer and praising God (cf. Acts 2:42-47), should present themselves as a sacrifice. (pp. 360-361)

Naidoo (2015a; cf. Van der Walt 2015:158) makes the point succinctly:
... theological education no longer refers to university or seminary education alone, but to efforts on the part of the whole Church to learn from its rich traditions. There has been a reappraisal of the status and role of the laity in many Christian traditions. ... Ministry is no longer solely equated with the activities of ordained ministry, but rather something exercised by the entire people of God, in church and around the world. (pp. 3-4)

This is the role of diversification (Van der Walt 2016:157). The task of caring and healing is not limited by NQF levels. As a result, a proposed new qualification (NQF level 5) provides the stimulus for the design of an appropriate programme at Higher Certificate level, which transcends mainline and what Van der Walt calls 'informal churches' (I would prefer to avoid these typological labels and refer simply to 'churches', though some clearly have far more resources than others, which is a relevant factor here). Diversification needs to be seen in terms of needs. It is extremely important that practitioners receive appropriate training, because they are engaged in the age-old vocation of the care and cure of souls, a sensitive and delicate process in which things can go terribly wrong if exercised by untrained practitioners. It is open to abuse by well-meaning people with a heart for the work but no expertise and by those who believe counselling people is about giving advice, which can do more harm than good, rather than helping the broken to discern their issues and resources and to find their own way forward.

Van der Walt (2016:158) suggests that there are few opportunities available within the formal educational sector for this kind of training at an appropriate level for those who cannot access programmes at appropriate entry levels, often because of their historically disadvantaged education (Van der Walt 2016:161). Many are in full-time employment and have limited opportunity for full-time training. Drawing on Kinsler's (2009) experience and insights, two relevant issues arise. Firstly, 'to follow Jesus in our time ... we need to consider whether our programmes of theological education are equipping local church leaders to defend and support the weak' (Kinsler 2009:19). Secondly, 'priority should be given to the meaningful theological formation of local leaders, especially those who have been traditionally marginalised' (Kinsler 2009:15). The focus is on local leadership and is consonant with a missional approach to the mission, vision and identity of the church.

One issue is that any of these leaders have to be trained at a pre-tertiary level, specifically NQF levels 2, 4 and above. However most, in particular smaller and less wellresourced, ministry training institutions have experienced difficulty in registering as Further Education Training centres to offer such programmes. Such courses are not recognised as credit bearing, which means that they cannot contribute towards recognised qualifications. Further, the process of registration is complex. Theology and religion are not accorded a place in the Sectoral Education and Training Agencies and are, therefore, not eligible for assistance from the Skills Development Fund. It is also expensive and often beyond the means of smaller, poorer churches. Van der Walt (2016:163) also points out the lack of an agreed common mission and vision strategy among potential providers. This in turn negatively impacts upon curriculum design, development of resource materials and the provision of expert facilitators.

Thus, there is a need for greater diversification within the regulatory framework, particularly at the lower levels of attainment. The NQF Act (2008) provides for non-statutory professional organisations as part of the Department of Higher Education and Training's Organising Framework for Occupations (SAQA 2012:5) in terms of a 'community of expert practitioners'. This allows for the recognition of nonstatutory professional bodies competent to develop curricula and assessment standards. This will enable each professional body to determine its own peculiar characteristics and standards. Van der Walt (2016) summarised the outcome:

... the opportunity to develop a fully diversified and flexible training dispensation for leaders in the informal church environment who need access to formal, recognised training $[\ldots]$ can finally be opened up. (p. 167)

This will 'fit the need structures of pastors, in particular those of the informal churches and the growing number of "lay" workers in informal as well as formal (historic) churches' (Van der Walt 2016:168).

Towards this end the ACRP was formed in 2014 through the merger of the Association of Ministry Training Practitioners and the South African Association for Pastoral Work. This was the result of the suggestion of SAQA, because both Christian bodies had applied to be registered as professional bodies. The ACRP's focus centres on the principle: 'To pursue the formal professionalisation of religious (church, ministry) practice within the Christian tradition, with a particular focus on the needs of the independent/informal church environment' (ACRP Memorandum 2017:1). It developed Christian Ministry qualification at NQF level 2 during 2015 and 2016, Christian Ministry qualification and an NQF level 5 in 2016. 


\section{Association of Christian Religious Practitioners Memorandum of Incorporation}

Objectives:

1. professional support to and the registration of Christian religious practitioners

2. promoting the training of Christian religious practitioners, with a particular, but not exclusive, focus on the training of educationally disadvantaged persons who want to access education and training on higher levels.

We note the emphasis on support for previously disadvantaged persons' formation. This is a long-term rather than a short-term strategy, especially for those who may encounter problems of access. This is the source of the ACRP, which is an initiative of pastors, churches, training institutions to create a body that could apply to SAQA for recognition within the government's regulatory framework. Consequently, the ACRP defined the components of professionalisation as defining professional designations, linking training standards, registering ministry persons on a professional database and identifying SAQA-accredited ministry qualifications. All of this leads to cooperation with churches and other ministry institutions. The professional council is responsible for producing a generic ethical code, code of good practice and disciplinary code; maintenance of good practice; supervision and protection of the public (Erasmus 2017). Hence, we note the setting of criteria and promotion of professional development, monitoring compliance and cooperation with SAQA.

Association of Christian Religious Practitioners Rules Document:

\section{Mission of ACRP}

The mission of ACRP is to support Christian religious practitioners in fulfilling their calling and promote the provision of training to Christian religious practitioners.

2. Objectives of ACRP

ACRP seeks to assist ministry leaders (including pastors, counsellors, missionaries, youth workers, etc.), as well as churches and other ministry institutions as employers, by fulfilling the functions of a professional body in respect of Christian religious practitioners. This is done by means of the following:

- Providing professional support to and registration of Christian religious practitioners ...

- Promoting the training of Christian religious practitioners, with a particular, but not exclusive, focus on the training of educationally disadvantaged persons who want to access education and training on higher levels.

With regard to the $S A Q A$ Act, its remit is based in the 'monitoring and auditing $[o f]$ achievements' (2.1). Its accreditation focus is on the end product of the education we offer in terms of quality assurance processes related to 'the identified mission' of a particular sector; 'its activities will advance the objectives of the National Qualifications Framework' (3.1.i).

The emphasis here, in continuity with the $S A Q A$ Act, is on the benefit of the individual and society. A significant aim is the protection of clients from unscrupulous service providers. This aim appears to be limited to the South, southern and sub-Saharan region of the African continent.

1. Affiliation

There are two types of affiliation to ACRP, namely individual registration and institutional affiliation.

\section{Individual affiliation (registration) to the Association of Christian Religious Practitioners}

- General: Individual affiliation (registration) is defined by Ministry Councils in terms of designations. Practitioners have the option to be affiliated to (registered with) more than one Ministry Council if the requirements for registration as set by those Boards have been met. Fees will be determined in accordance with the level of affiliation (registration).

- Designations

- 'Religious Specialist' ...

- 'Religious Professional' ...

- 'Advanced Religious Practitioner' ...

- 'Religious Practitioner' ...

\section{Categories of institutional affiliation to the Association of Christian Religious Practitioners}

- Training provider affiliation: There are three levels of training provider affiliation:

- Accredited Independent Training Provider ...

- Accredited Supported Training Provider ...

- Non-accredited Training Provider ...

- Church, church network, ministry or faith based organisation affiliation ...

- Associate institutional affiliation ....

- This category provides for non-ministry related organisations that support the cause of the ACRP ('friends of $\left.\mathrm{ARCP}^{\prime}\right)$.

A Recognition of Prior Learning (RPL) process is also applicable in awarding designations. Among the criteria taken into account are 'fundamental knowledge and skills; competence; scope of learning; responsibilities; learning pathway, experience and professional status; and research track record'.

\section{Benefits and/or dangers}

It may be difficult to designate a concern as either a benefit or a danger because different role players may see issues from different perspectives, as is the case with the NQF and training providers (see Dunsmuir \& McCoy 2015:27-41). Further, some concerns may be seen as threats in specific circumstances. Hence, there may be a discrepancy with regard to an issue being regarded as a benefit or a danger. 
This may be obviated if all role players can adopt the position of participants in a national venture to provide and facilitate the best education for our learners throughout South Africa. This is what the legislation seeks to achieve in a serious attempt to add value to the system in a fluid context. Sadly, some appear to resist and resent the attempts to develop a just educational system at this significant and critical time in our nation's history. This is not consistent with a position that wishes Christian Theology to remain part of the academy while also wishing it to be treated as a special case.

We live in a dynamic culture at a dynamic period of time. The only thing that is constant is change, and it takes courage to embrace change. The tendency within church or religious circles is to maintain that we provide a static refuge from the effects and impact of change in our society. Yet the semper reformanda principle, derived from the Reformations and possibly even earlier, which indicates that the church is reformed and always [in need of] being reformed according to the word of God, reflects a Spirit-guided approach to change. Whoever saw the Spirit of God taking a break, even a well-deserved one? Dynamism is its nature and we are called to be human dynamos - inspired within the contexts in which God has placed us. And that context is Africa.

A nationally recognised 'professional qualification accredited by a regulated body' (regardless of the NQF level) raises the quality of what is being offered in the pastoral domain as well as the quality of the provider. It removes the oftexpressed image of the overzealous, fanatical religious caregiver who may do more harm than good. While not in the original Hippocratic Oath, the principle of 'first, do no harm' resonates throughout the oath (Tyson 2001:1). This is as much a premise of pastoral care (cure of souls) as of medical care. Then there is the benefit of standard setting and maintenance, evaluation, monitoring and supervision linked to lifelong learning offered by an oversight body within the professional body itself and nationally with international possibilities. Such a benefit will always be enhanced by close links between such bodies and the sharing of new developments and expertise. Recognition is a valuable commodity within the caring professions. It can be linked to collegiality, a derivative of cooperation, consultation and a sharing of ideas, opportunities and challenges. This is extended to include the ability to make representations to the regulating body. It offers practitioners a sense of self-worth and professional identity along with a deeper sense of purpose. It may lead to developing a greater sense of pride in work, with the concomitant danger of such pride slipping into arrogance (a problem in any profession, but perhaps less of a threat in a vocation). While there is always the danger of gathering qualifications as an end in themselves, this is less likely at the lower NQF levels. In this context, they are more likely to be a means towards providing a more meaningful integrated faithful service.

Distance education programmes present special problems, including confusion, as they are often contact programmes sent by post or email. There needs to be a recognition that distance learning is a special approach to education that requires expert designers to ensure that the programme is fit for purpose. There are clear regulations about the provision of contact and distance learning programmes (CHE Criterion 6: Student Assessment Policies and Procedures). Yet distance education opens up new vistas for many who have been excluded from formal educational opportunities in the past.

Staffing poses its own problems when the size and capacity of an institution do not allow for a substantial full-time staff contingent. Some institutions' staff have inadequate or unverified qualifications. Then there is a lack of one or more of the following policies: workload models, assessment practice, staff development and staff equity. Then it is possible that no performance assessment of staff is done (CHE Criterion 3: Staffing [qualifications, experience and competence]; CHE Criterion 4: Staffing [size, seniority and employment conditions]).

One of the dangers is self-indulgence. Because we are 'religious', we often allow ourselves to think and believe we are not as accountable for what we do and how we behave as other vocations and so things can go so badly wrong, as we have seen with high-profile American tele-evangelists, for example. We may note the examples of sexual misconduct by internationally recognised high-profile evangelists like Jim Bakker (Bauer 2008:115-142), Jimmy Swaggart (Bauer 2008:143-151) and Cardinal Bernard Law (Bauer 2008:183206), who often justify immoral acts as acceptable, which is a vital ethical issue in this study. Surely, if standards apply at all, ours must be beyond reproach. I think this is one of the reasons for the antipathy of churches and church-related institutions towards the CHE. There have been some very poor examples of Christian praxis here. We need to remember that one of its main functions is to protect learners from unscrupulous theological entrepreneurs who have their own theological (read: ideological) agenda.

Relationships provide another unwitting danger point for private institutions. The $\mathrm{CHE}$ strongly discourages partnerships between private higher education institutions (PHEIs) and public institutions. Public institutions benefit by receiving subsidies for students they do not teach while the partnered private institutions provide the staff to meet the public institution's teaching responsibilities. One concern is that such relationships discourage PHEIs from developing their own capacity. Of course, there are benefits to be derived from appropriate relationships such as cooperation, sharing resources and use of staff for external examination.

Another danger is insecurity, which comes from our commonly held assumption that good pastors and academics are also good teachers. This is not a logical or reasonable conclusion to reach in many cases. Here we strike a very sensitive nerve. In many contexts there is a limited understanding and implementation of appropriate and current teaching, learning and assessment and moderation approaches. Institutions lack an underling philosophy of education, which is the direct result of having 
few or no trained educators. How many of us have taken time and trouble to familiarise ourselves with current trends in education and teaching methodology, and how open are we to take the risk of embarking on life-changing practice arising out of a commitment to lifelong learning? For instance, there are modes of facilitating learning other than lecturing.

In the majority of instances infrastructure is inadequate and library resources insufficient to the extent that the delivery of quality educational programmes is severely affected (CHE Criterion 7: Infrastructure and Library Resources). Very often the lack of adequate resourcing impinges directly on the academic programme. As a result of the lack of a variety of appropriate reading materials, learners may just read enough prescribed material to 'get by'. This is not an adequate approach to higher education. Yet the regulatory environment does not appear, at this stage, to have given appropriate consideration to the vast array of resources available online. A number of higher education providers are further ahead in this field.

Assessment in particular is a vexed area. Facilitators seem unable to determine the link between learning outcomes and assessment criteria. Consequently, this may lead to poor assessment practices. This is exacerbated by the absence of external moderation and guidance in assessment practice in many institutions. Often learning outcomes are not specified and learning materials are often too basic. All in all, curriculum choice is limited (e.g. Hebron Theological College 2017; South African Theological Seminary 2017). We realise that developing and evaluating learning materials is problematic in some institutions where there is no clarity regarding who designs and develops teaching materials. Often it is left to the subject expert, who may have little knowledge, interest or expertise in communicating his or her knowledge. Then, in no case is there what can be defined as work integrated learning or service learning as an integrated part of the modules as a part of the credit-bearing purpose. This leads to the danger of operating without regard to the integrity of our institutions and purpose.

A problem here is that we are using the training we have received to follow one vocation (ministry) in a manner that denies the validity of further training to enter another 'profession' (education, pastoral care). How many institutions sponsor staff to undertake qualifications in teaching at Private Higher Education Institutions (PHEIs)? They rather focus on purely academic development to the detriment of professional advancement. The situation is worsened when theological convictions and denominational and/or confessional affiliation impinge on the academic quality of programmes. In contradistinction to this approach is the widely acknowledged 'need to construct an African hermeneutic for theological education' (Higgs 2015:53) through a context-focussed curriculum. The cardinal aim is to foster academic excellence in theological education through ensuring the academic function is not undermined.
Another danger is pride and insularity. I think that as academics we are not aware of how much we learn from our students and how much we owe to them. Some are even so arrogant that we think that students can teach us nothing. This is evidenced in student complaints made to me personally regarding the maintenance of the traditional lecture system as a sole means of teaching, an unwillingness to embrace contemporary innovative methodologies and a refusal by lecturers to entertain questions, discussion and even critical comments. A dialogical pedagogy is grounded in the praxis of 'the teachers need to learn, and the learners need to teach' (De Gruchy \& Ellis, in Nell 2016:1232). At the launch of one of his books in Rome, the theologian Bernhard Häring stated, 'I have learned all my theology from the poor of the world' (Dowling 2016:4). I cannot claim the same because I have learned all my relevant theology from my students here in Africa, after receiving a European theological education.

What we need is an authentic commitment of support for our students, who hold the future of our nation in their hands, if we are prepared to entrust that future to them as previous generations did to us. We are responsible for handing on the traditions of our churches. The work of Thomas Oden verifies this even in the context of contemporary pastoral care:

I have tried to set forth what is most commonly said in the central Christian tradition about ministry. I have tried to distil the best ideas of the two millennia of ecumenical Christian thinking concerning what pastors are and do. My purpose is to develop an internally conscious grasp of classical Christian thinking about the pastor and to provide a minimal foundation for that knowledge of the pastoral office requisite to the practice of ministry. (Oden 1985:vii)

What is also relevant is Oden's conviction that historically the African continent has played a role here (Oden 2010).

We are not clear about what lies ahead but our Lord and God even appeared through closed doors and gates to offer fresh opportunities for service. Closed city gates never held the apostles back, whether they were inside or outside the gates. Paul, in Acts 9:23, even bypassed the gates when they became a barrier to the progress of the gospel. However, now to our context, where one of my students proclaimed:

It took studying at the University of Pretoria (UP) for me to appreciate my Blackness and the history it comes from. It was through being challenged by Prof. X and Prof. Y that I began to ask myself 'what does it mean to be black in a world that is defined through biases and subjective thoughts?' And so I submit that this journey is one of self-discovery, painful, full of struggle but mostly about the restoration of human dignity and the realisation that the Gospel is not exclusive but is for the masses, bringing all to the core of God's love ... No sermon in Africa can ever be given if it does not reflect its context. \#proudtukkie \#theologian \#black african. (Kabelo Motlhakane, 15 February 2016)

This is a most encouraging comment from a student - we must be doing something right, but is this how our programmes impact on all students? However, we must beware. Our partners from the churches often complain that 
they 'find leaders who have excellent academic qualifications, but lack spiritual wisdom, maturity and ministry competence' (Nell 2016:1230) and they have been doing it as part of their diagnosis of the long-term crisis in theological education. We find comments such as:

We cannot train men to 'rock the boat, but we must not stifle their ability to do this'. (MTCFTS, 18-19 July 1972, S3050/21/7/72, William Cullen Library, Wits University, AB2414, B8, M6, in Duncan 2016a:42)

Yet, an aspect of Fedsem's problems emanated from its amazing and consistent success rate in producing a crop of young radical priests who went out to shake things up in both church and society. In time, even the churches began to 'fear'. The churches had created the monster they came to resent and fear, but they had invested too much in promoting Fedsem and a successful ecumenical and non-racial experiment to give it up. (Maluleke 2006:305-306 in Duncan 2016:43)

A subcommittee on theological education of the Church Unity Commission, representing the Anglicans, Congregationalists, Methodists and Presbyterians and recently joined by the Lutherans, and Notes from the Committee on Theological Education has also recently raised the issue, 'What is the interface between authority and power and how do we educate appropriately, theologically?' (e-mail Paul Verryn to author, 02 November 2017). All of this relates to boundaries and expectations in the educational sphere.

At the present time, theology is under severe threat in South Africa from secular forces within and beyond universities, which are 'shaking the foundations' (Tillich 1948). Our somnambulance may soon lead to the discovery that theology has been displaced by religious studies, which has a durability theology lacks in the eyes of the South African government and many in the academy. Theology is viewed as a privileged broad discipline in the academy, favouring only one faith expression, with a history of alignment to apartheid policies rather than reconciliation as 'an imperative for conscious policies, while religious studies is a humanities subject which is far more inclusive. Yet, theology has the capacity to be a source of social intervention in order to promote processes of restoring justice and renewed relationships' (Nordstekke 2013). It:

offers the promise of a 'reconciled diversity' (Atzvi 2013:34) as an enhancing dimension of life achieved through 'processes of dialogue, mutual learning and understanding which cultivate a spirit of respect and inclusiveness, with the ultimate wish to ensure a peaceful and reconciled co-existence'. (p. 117)

We need practical wisdom (phronesis) to navigate the tempestuous waves of the social, political, cultural and economic implications of what we have embarked on as educators.

Another danger is static adherence to Western traditionalism, even in the field of pastoral care, pastoral counselling and pastoral ministry, where the focus of care is the individual rather than the group or community, which is the unit of identity in African societies. Do we as teachers and academics have the wisdom to move forward from our well-defined and protected positions? Do we have the courage to progress through the gateway as academics? It is one thing to open the gates for our students to walk through but do we have the courage to go there (where no one has gone before) ourselves? This leads us to the need to interrogate the hegemony of our Western-based curriculum. Naidoo (2016) asserts that this Western 'dominant curriculum [of theological educational institutions] continues to be a source of alienation' within Africa. This appears as a global crisis of confidence in the normativity of Western Christianity (Duncan 2016:8). For example, at the University of Pretoria, a public institution:

The major issue facing theology at the UP as it works towards the future is the transformation of the faculty from a Eurocentric entity into an African faculty. This is controversial because FT prestige depends to a great degree on how we fare in the various world ranking systems rather than seeking to realise our full potential in Africa, our natural habitat. (Duncan 2016:7)

The new curricula for the BDiv and BTh degrees were introduced in 2010 and 2011. Phase one introduced the veneer of Africanisation, but the European-based philosophical underpinning remains intact. (Duncan 2016:8)

This is true of both private and public institutions. Any change built on this base simply maintains the status quo (cf. Duncan 2016:6-12). In how many cases is the allocation of funds responsible for the nature of our curriculum? A number of institutions' curricula are determined by the same content of programmes on offer at sponsoring institutions in other parts of the world. Global University is a fully accredited (in the USA) for-profit Christian university, in the Pentecostal tradition, based out of Springfield, Missouri. As a worldwide distance learning pioneer, the university integrates education and service through a network in 150 countries, (e.g. Global University at Global School of Theology, South Africa 2017).

\section{Resistance to promotion of all things African}

Pobee (2010:338) is not correct in his assertion that theology in Africa began with a North Atlantic paradigm and artefacts, which also short-changed African identity, ethos, use and creativity. Theology began from the earliest stage in the life of the church and is well attested to in the work of theologians like Origen, Cyprian, Tertullian and Augustine. However, his statement is true in that in its modern manifestation from the 18th century, Western theology dominated developments in Africa.

Jean-Marc Ela (1988) articulated a contemporary concern:

In Africa, the confrontation between the message of the gospel and the African universe must bring forth a meaning with the poor to transform the lives of African Christians. Today, the faith of the church in Africa is in danger of death, because the church tends to forget its cultural dimensions as marked by its Greco heritage. If the faith of the Africans is not to die, it must become a vision of the world that they can feel in theirs; European cultural dimensions must be stripped away. There is an urgent need to reject present foreign models of expressions, if we are to 
breathe new life into the spoken Word. Our church must express a Passover of Language, or the meaning of the Christian message will not be understood. One of the primary tasks of Christian reflection in black Africa is to tally, reformulate our basic faith through the mediation of African culture. In place of the cultural presuppositions of Western Christianity, namely logos and ratio, we must substitute African symbolism. (p. 44)

Within the South African context, Naidoo (2015a:6) confirms that 'most of the theological reflection remains captive to a Western model of theologising, reflecting the tension between African communal culture individualism, and the competitive characteristic of Western culture'. Naidoo laments the dissonance between formation and the traditional intellectual approach. Virtually all institutional mission and vision statements emphasise the desire to serve the African context, but this is more honoured in the breach than the observance. When the curricula of, for example, South African private providers of theological education are analysed, nowhere is the African context mentioned either in their mission statements or curricula (e.g. Hebron Theological College 2017; South African Theological Seminary 2017). By comparison Mukhanyo Theological College (2017) mentions 'training for ministry in the African context', but it is not clear how this is achieved in its syllabi. It is as if we are not proud of our African heritage or we are not even aware of it. We should remember that the first Christian university was founded in Alexandria in Egypt centuries before the rise of the medieval university in Europe. Along with the Islamic university at Timbuktu, these were the first (African) higher education institutions. Africanisation is possibly the most critical issue that needs to be addressed in South African education today. We continue to impose curricula that are designed outside South Africa for other contexts. This is because our theological education has jettisoned its African heritage in favour of the European and from then it only returned in the 19th century. Envisioning a post-colonial approach to theological education, Namsoon Kang (2010), writing in the context of long-term widespread dissatisfaction within the Protestant mainline denominations' theological education programmes (cf. Cochrane 1992:2, De Gruchy 1996:23, Denis \& Duncan 2011:245, 247), comments:

One cannot simply write a kind of 'universal' perspective on the theological education in world Christianity. If one does, it would be an act of homogenisation through the lens of the discursively powerful. ... There is a deep seated 'suspicion' among scholars primarily due to the 'foreign' or 'western' origin. (p. 31)

These require totally different approaches, at least initially, in order for a contextual model to be developed without the encumbrance of past colonial models, as they operate from differing epistemological assumptions. Otherwise, there can be no basis for dialogical encounter. However, Guder (2010) affirms that:

these processes obviously need to interact with and inform each other, because their common basis is the Christendom project both in its continuing influence in the west and its impact upon the non-western world mediated by the modern missionary movement. (p. 53)
Steve De Gruchy (2010), referring to the colonial missionary legacy, states:

Without the chance to deconstruct this legacy during one's training, there is little possibility of pursuing a creative reconstruction in a post-colonial era ... to seek ways to reconstruct it in creative and energetic ways. ... Studying the colonial missionary legacy is vital for this, because it also serves as a reminder to the arrogance and self-righteousness that can come so easily to characterise the churches of the South/East too. (p. 49)

It is important to take account of the 'burgeoning growth and emergence of global Christianity in the 20th [and 21st] century' (Guder 2010:51) in the context of 'the disintegration of western Christendom', which, in its day, 'worked'.

\section{Resistance to promotion of all things African}

Virtually all institutional mission and vision statements emphasise the desire to serve the African context but this is more honoured in the breach than the observance. It is as if we are not proud of our African heritage or we are not even aware of it. We should remember that the first Christian university was founded in Alexandria in Egypt centuries before the rise of the medieval university in Europe. Along with the Islamic university at Timbuktu, these were the first (African) higher education institutions. Africanisation is possibly the most critical issue that needs to be addressed in South African education today. We continue to impose curricula which are designed outside South Africa for other contexts. This is because our theological education has jettisoned its African heritage, in favour of the European and waited for it to return in the 19th century. However, as the result of this long wait there has been little if any inculturation. Here we come across basic differences that cannot be ignored. Baloyi (2017:1) explains the basic difference between pastoral care in African and European contexts - the European characterised by life lived as individuals and the African context as 'life experienced as a whole'. These require totally different approaches. This touches on the topic of relevance (CHE Criterion 1: Programme Design; CHE 2004, 2013). No concession is made in the programme design to the fact that our institutions offer courses in Africa. All theological programmes conform to Western models and values.

The South African (SA) context needs to be respected and catered for, and all programmes must be aligned with the Higher Education Quality Sub-Framework (HEQSF). Theology is a critically contextual endeavour, and international programmes cannot simply be carried over into SA without properly translating such programmes and integrating them into the African context. In addition, assessment procedures should reflect the SA environment (e.g. use of credits and marks allocation) in order to allow for articulation and to ensure proper, conversant structures. At times external or international, sponsoring institutions' administrative operations have been simply transferred to SA institutions - for example, some institutions use US assessment standards (grade point average system). 
This does not indicate that the qualification is obtained in South Africa, nor does it indicate the HEQSF credits and levels (Criterion 8: Programme Administrative Services; CHE 2004, 2013).

In terms of theological education Africa needs to 'get in step with Christianity as an African religion at an epistemological level' (Balcomb 2014:72, 74-75). This was attempted by De Gruchy and Chirongoma (2007:291-305) in their analysis of the distinguished history of Christianity in Africa using the primal elements of earth, water, wind and fire as reference points of influence in the past that are still relevant in contemporary Africa. This is true with regard to the critical issues of 'religious pluralism, climate change, globalization and poverty, war and violence, refugees and xenophobia, HIV and AIDS, TB, malaria and cholera, rape and domestic violence and the like' (De Gruchy 2010:47). According to Kombo (2016:1224-1225), it is imperative that theological education provide 'spaces for formation' where there may be engagement with the contextual challenges presented by the four images. PHEIs can provide such spaces. I tend to agree with Kombo (2015), who views the development of Christian doctrine as a:

deep, reflective, consistent and relevant interaction with both the African as presently presented on the one hand and in a manner that is consistent with the roots of Christianity in the early church on the other hand. (p. 3)

And a major root of Christianity historically is to be found in Africa. However, one of the problems we face is that no one has prepared the main actors in this drama-African leaders, as can be seen in the hitherto unresolved equity issues in both public and private education providers. Of course, this is related to power issues including race, gender, nationality, language and professional status (De Gruchy \& Ellis 2008:19). One way to resolve such a dilemma is by participation and collaboration, which is what the NQF and CHE advocate.

Higgs (2015:43) advocates 'a reconstruction of theology specifically for Africa by Africans in which African indigenous knowledge systems' are privileged. Africanisation and/or transformation processes must be marked by authenticity and integrity. Guiding principles in such a paradigm change are suggested by Carpenter (2014:125-129): the reintegration of theological disciplines, reconstruction of systematic theology, re-grounding theological discourse, re-engaging other ideologies and traditions and renewing the theological mind. To these might be added recognising 'primal spirituality' (Fotland 2014:116) as a universal spirituality and the prioritising of eco-justice. Our reflections must revolve around the question: do we have the capacity and commitment for such a long-term reorientation?

Some are able to reach the stage of liminality (so far but no more), a very uncomfortable place to be because going backwards in such a situation is never a clever option. The only options are standing still, remaining with a commitment to what we know and are comfortable with, though no one can poise themselves for too long on a tightrope, or taking Kierkegaard's 'leap of faith', where the 'leap is the decision' (Kierkegaard 1847, in Hong 1993:102), into an uncertain and risky future and grasping all the opportunities that present themselves. That is no choice at all in facing the 'courage to be[come]' (Tillich 1952).

\section{Evaluation}

The recently formed ACRP:

holds the potential for ministry training institutions to overcome the challenges that ... prevented a large proportion of leaders from entering into a recognised progressive path of theological education and ministry training. (Van der Walt 2016:168)

and:

where the diverse needs of the large number of leaders in the informal church environment - many of whom can be described as little, marginalised ones for whom there is a special place in the heart of Jesus we met in the gospel - will be met with appropriately diverse and adaptable training solutions. (Van der Walt 2016:168)

Anything that contributes to a widening of access is a positive step in SA education and can enhance the confidence and competence of many who believe they are not capable of reaching such heights of achievement. The role of RPL is vital here as a mode of transition into the formal sector of higher education.

This development of accreditation raises the issue that government bodies cannot be the only source for the assessment and accreditation of theological institutions. The church will need to assist the theological institution in redefining the meaning of ministerial profession, the role of leadership and the educational formats that will serve the goals that emerge from these conversations (Dunsmuir \& McCoy 2015:38-53; Naidoo 2015b:169-170, N.18):

[F]or this a habitus is necessary, 'an integrated curriculum' (Naidoo 2015a:176). Naidoo (2015a:177) further suggests that 'The inner coherence and church-related responsibility of theological education cannot be exercised if the structural framework does not allow a formational emphasis'. This requires an integrated approach where: Integration refers to attempts to synthesise and coordinate the major learning experiences in a programme. It includes the integration of theological disciplines with each other; the integration between theory and praxis; and the dynamic interplay of knowledge, practice, and context knowing, doing and being. (Naidoo 2015a:178)

The current educational system in South Africa is characterised by formal accreditation based on the achievement of 'minimum standards'. However the aim of the church in theological education is far more than achieving minimum standards (Dunsmuir \& McCoy 2015:27).

The new system allows for the growth of confidence among churches in the system and for articulation nationally and internationally. There is a desire for accreditation, as can be seen from the time of the demise of the Federal Theological 
Seminary of Southern Africa (FedSem) in 1993. In this matter, Duncan (2004:18) referred to the existence of 'open access to subsidised alternatives', specifically, state universities that now accepted black students.

Dunsmuir and McCoy (2015:30) raise the question regarding the ability of programmes that lead to qualifications in theology being able to meet the requirements of preparing people for ministry. However, the same question might appropriately be asked of accredited programmes that prepare people for the vocations of inter alia medicine, social work and the law.

Practical wisdom (phronesis) is needed to navigate the tempestuous waves of the social, political, cultural and economic implications of what we have embarked on as educators in line with what Farley (1983:35) termed habitus the 'cognitive disposition and orientation of the soul, a knowledge of God and which God reveals', which results in the integration of faith and reason as partners on formation. It is 'holistic personal formation and transformation'. Dunsmuir and McCoy $(2015: 32,38)$ question how this may happen within the regulated environment. Two suggestions may be made here. One points to the value of the Reformed churches' curatoria, many of which are situated within the faculties of theology in which they train their ministers. This allows for the necessary engagement of faith and reason. Secondly, is the aspect of work integrated learning, which allows for creative development of means of expression, which can be integrated into the credit module and given the credits it deserves through supervised practice, as in Clinical Pastoral Education

Contrary to Dunsmuir and McCoy's suggestion (2015:33), accreditation has been generally accepted and some institutions and bodies, such as the ARCP, have developed creative means of working within a regulated system.

\section{Conclusion}

Significant progress has been made both in the achievement of an equitable education system in South Africa since 1994 and, despite problems within the theological education sector, great vigilance is being exercised in order that faith concerns be addressed appropriately. Private higher education providers, despite the many problems they face, are making a serious attempt to comply with national regulatory requirements and meet the needs of their clients (churches, organisations, groups and individuals). Those who are committed to responsible engagement with a view to the constant improvement of all things that further the vision and mission of both the nation and the church are to be commended.

What looks like progress is often regress, but much more needs to be done. A glorious future awaits us if we have the 'courage to be'. Religion has an amazing history in Africa; its compass is comprehensive and holistic - it has much to teach the rest of the world.

\section{Acknowledgements Competing interests}

The author declares that he has no financial or personal relationships which may have inappropriately influenced him in writing this article.

\section{References}

Amanze, J., 2010, 'Ecumenical formation in theological education: African perspectives', in D. Werner, D. Esterline, N. Kang \& J. Raja (eds.), Handbook of theological education in world Christianity, pp. 111-118, Cluster Publications, Pietermaritzburg.

Association of Christian Religious Practitioners (ACRP), 2017, Memorandum (Version 3.0 - Update 6 March 2017), ACRP, Pretoria.

Atzvi, K., 2013, 'Ecumenism as reconciliation', in R. Schreiter \& K. Jorgensen (eds.), Mission as ministry of reconciliation, pp. 30-36, Regnum, Oxford.

Balcomb, A.O., 2014, 'Shifting the theological paradigm in Africa - Building on the legacy of Kwame Bediako', in G.M. Bediako, B.Y. Quarshie \& J.K. Asamoah-Gyadu (eds.), Seeing new facets of the diamond: Christianity as a universal faith, pp. 6780, Regnum, Oxford.

Baloyi, M.E., 2017, 'The challenge of pastoral care in African context', Paper delivered at the founding conference of the Association of Christian Religious Practitioners (ACRP) on 'Professionalisation of (Christian) religious professions within the context of the South African regulatory framework', Pretoria, 25-26th August.

Bauer, S.W., 2008, The art of public grovel: Sexual sin and public confession in America, Princeton University Press, Princeton, NJ.

Carpenter, J.A., 2014, 'Christian thinking in an age of Christianity, fresh opportunities for theology in the west', in G.M. Bediako, B.Y. Quarshie \& J.K. Asamoah-Gyadu (eds.), Seeing new facets of the diamond: Christianity as a universal faith, pp. 118-131, Regnum, Oxford.

Cochrane, J., 1992, Theologia in South Africa: Facilitating a redemptive community through formation and training, ASATI workshop, University of the Witwatersrand, Unpublished paper.

Commission for the Promotion and Protection of the Rights of Cultural, Religious and Linguistic Communities (CRL Rights Commission), 2017, viewed 03 September 2017 , Linguistic Communities (CRL Rights Commission), 2017, viewed 03 September 2017,
from https://www.facebook.com/pg/CRL-Rights-Commission-121873527945849/ from https://www.facebout/?ref=page_internal

Council on Higher Education (CHE), 2004, Criteria for programme accreditation, CHE, Pretoria.

Council on Higher Education (CHE), 2013, The higher education qualifications subframework, $\mathrm{CHE}$, Pretoria.

De Gruchy, J.W., 1996, 'From the particular to the global: Locating our task as theological educators within the viability study process', Bulletin for Contextua Theology in SA and Africa 3, 20-24.

De Gruchy, S., 2010, 'Theological education and missional practice: A vital dialogue', in I.A. Phiri, D. Werner, C. Kaunda \& K. Owino (eds.), 2016, Anthology of African Christianity, pp. 42-50, Regnum, Oxford.

De Gruchy, S. \& Chirongoma, S., 2007, 'Earth, water, fire and wind: Elements of African ecclesiologies', in G. Mannion \& L.S. Mudge (eds.), The Routledge companion to the Christian church, pp. 291-305, Routledge, New York.

De Gruchy, S. \& Ellis, W., 2008, Christian leadership in 'another country': Contributing to an ethical development agenda in South Africa today, Rozenburg, Amsterdam.

Denis, P. \& Duncan, G.A., 2011, The native school that caused all the trouble: A history of the Federal. Theological Seminary of Southern Africa, Cluster Publications, Pietermaritzburg.

Dowling, K., 2016, 'Bishops as theologians: Listening, discerning and dialogue', in A.E. Orobator (eds.), The church we want: African Catholics look to Vatican III, pp. 3-10, Orbis, Maryknoll, NY.

Duncan, G.A., 2004, 'Its end foreshadowed in its beginning: The closure of the Federal Theological Seminary', Studiae Historiae Ecclesiasticae XXX(1), 1-31.

Duncan, G.A., 2016a, 'Gateway to the future ... oopmaak van die hekke Transformation in the Faculty of Theology, University of Pretoria', HTS Teologiese Studies/Theological Studies 72(4), a3424. https://doi.org/10.4102/hts.v72i4.3424

Duncan, G.A., 2016b, “'One in Christ": Fedsem spiritualities of solidarity', Acto Theologica 36(1), 27-50. https://doi.org/10.4314/actat.v36i1.4

Dunsmuir, C. \& McCoy, M., 2015, 'Accreditation and ministerial formation: Serving two masters', in M. Naidoo (ed.), Contested issues in training ministers in South Africa, pp. 27-40, SUN Press, Stellenbosch.

Eberly Center, 2015, Teaching excellence and educational innovation, Eberly Center for Teaching Excellence and Educational Innovation, Carnegie Mellon University, viewed 26 December 2017, from http://www.cmu.edu/teaching/

Ela, J.-M., 1988, My faith as an African, Orbis, Maryknoll, NY.

Erasmus, T., 2017, 'From the old to the new', Paper delivered at the founding conference of the Association of Christian Religious Practitioners (ACRP) on 'Professionalisation of (Christian) Religious Professions within the Context of the South African Regulatory Framework', Pretoria, 25-26th August.

Farley, E., 1983, Theologia: The fragmentation and unity of theological education, Fortress, Philadelphia, PA 
Flannery, A., 1975, 'Dogmatic constitution of the church, Lumen gentium, 21 November 1964', in A. Flannery (ed.), Vatican Council, vol I, The conciliar and post conciliar documents, pp. 350-426b, Costello Publishing Company, New York.

Fotland, R.G., 2014, 'Double religiosity in Norway: The persisting presence of primal religiosity', in G.M. Bediako, B.Y. Quarshie \& J.K. Asamoah-Gyadu (eds.), Seeing new facets of the diamond: Christianity as a universal faith, pp. 105-117, Regnum, Oxford.

Global School of Theology, 2017, viewed 27 December 2017, from ww.netpages.co. $\mathrm{za}$ /Roodepoort/Global+School+Of+Theology-237811.htm

Global University, 2017, viewed 27 December 2017, from https://www.globaluniversity. edu/about_index.cfm

Government Gazette, 1998, Government Notice: South African Qualifications Authority: Government Notice no. R 1127. Regulations under the South African Authority: Government Notice no. R 1127. Regulations under the South Africa
Qualifications Authority Act, 1995. Cape Town: Regulation Gazetter no. 6290.

Government Gazette, 2009, Act 67, National Qualifications Framework Act, vol. 524. Cape Town.

Grové, N.J., 2006, Principles of UP's Educational model (S 6144/06/[gewysig] University of Pretoria, Pretoria.

Guder, D., 2010, 'Theological formation for missional faithfulness after Christendom' in D. Werner, D. Esterline, N. Kang \& J. Raja (eds.), Handbook of theological education in world Christianity, pp. 51-55, Cluster Publications, Pietermaritzburg.

Hebron Theological College, 2017, viewed 27 December 2017, from http:// hebroncollege.co.za/

Higgs, P., 2015, 'The African Renaissance and the decolonisation of theological education', in M. Naidoo (ed.), Contested issues in training ministers in South Africa, pp. 43-56, Sun Press, Stellenbosch.

Kang, N., 2010, 'From colonial to postcolonial theological education: Envisioning postcolonial theological education - Dilemmas and possibilities', in D. Werner, D. Esterline, N. Kang \& J. Raja (eds.), Handbook of theological education in world Christianity, pp. 30-41, Cluster Publications, Pietermaritzburg.

Kierkegaard, S. [March 13, 1847], Hong, H.V. (eds.), 1993, Upbuilding discourses in various spirits, concluding unscientific postscript to philosophical fragments, Princeton University Press, Princeton, NJ.

Kinsler, R. (ed.), 2009, Diversified theological education: Equipping all God's people for mission, William Carry International University Press, Pasadena, CA, 296 p, viewed 28 December 2017, from https://www.thefreelibrary.com/Kinsler\%2C+Ross+\%28ed. $\%$ $29 \% 2 C+$ Diversified+Theological+Education\%3A+Equipping+All+...-a0192587973

Kombo, J., 2015, 'Role and relevance of theology for the future of African Christianity', in I.A. Phiri, D. Werner, C. Kaunda \& K. Owino (eds.), Anthology of African Christianity, pp. 1218-1227, Regnum, Oxford.

Küng, H., 1978, On being a Christian, Collins Fount, Glasgow.

Luther, M., 1520, Address to the Christian nobility of the German nation respecting the reformation of the Christian estate, The three walls of the Romanists: (a) The First Wall That the Temporal Power has no Jurisdiction over the Spirituality, viewed 29 December 2017, from http://media.bloomsbury.com/rep/files/primary-source74-martin-luther-address-to-the-christian-nobility-of-the-german-nation.pdf
Maluleke, T.S., 2006, 'Theology in my life', Reformed World 56(3), 302-307.

Motlhakane, K., 2016, '\#proudtukkie \#theologian \#black African (Kabelo Motlhakane)', Facebook 15 February 2016.

Mukhanyo Theological College, 2017, viewed 27 December 2017, from http://www. mukhanyo.ac.za/mission--vision.htm

Naidoo, M., 2015a, 'Introduction', in M. Naidoo (ed.), Contested issues in training ministers in South Africa, pp. 1-12, SUN Press, Stellenbosch.

Naidoo, M., 2015b, 'Ministerial Formation and Practical Theology in South Africa', International Journal of Practical Theology (IJPT) 19(1), 164-188. https://doi. org/10.1515/ijpt-2015-0004

Naidoo, M., 2016, 'Overcoming alienation in Africanising theological education', HTS Teologiese Studies/Theological Studies 72(1), Art. \#3062, 1-8. https://doi.org/ 10.4102/hts.v72i1.3062

Nell, I., 2016, 'Role and relevance of theology the future of African Christianity: A South African response', in I.A. Phiri, D. Werner, C. Kaunda \& K. Owino (eds.), Anthology of African Christianity, pp. 1228-1233, Regnum, Oxford.

Njoroge, N.J., 2008, 'Ecumenical theological education and the church in Africa', in Ministerial Formation, p. 10, Ecumenical Theological Education, Ecumenical Institute, WCC, Geneva.

Nordstekke, K., 2013, 'Diakonia in context: Transformation, reconciliation and empowerment', in R. Schreiter \& K. Jorgensen (eds.), Mission as ministry of reconciliation, pp. 112-125, Regnum, Oxford.

Oden, T.C., 1985, Pastoral Theology: Essentials of ministry, Harper \& Row, San Francisco, CA.

Oden, T.C., 2010, How Africa Shaped the Christian mind: Rediscovering the African Seedbed of Western Christianity, IVP, Downers Grove, IL.

Pobee J.S., 2010, "'Stretch forth thy wings and fly" - Theological education in the African context', in D. Werner, D. Esterline, N. Kang \& J. Raja (eds.), Handbook of theological education in world Christianity, pp. 337-346, Cluster Publications, Pietermaritzburg.

South African Qualifications Authority (SAQA), 2012, Policy and criteria for recognising a professional body and registering professional designation for the purpose of the National Qualifications Framework, Act 67 of 2008, SAQA, Pretoria.

South African Theological Seminary, 2017, viewed 28 December 2017, from https:// www.sats.edu.za/undergraduate/bachelor-of-theology/

Tillich, P., 1948, Shaking the foundations, Wipf \& Stock, Eugene, OR.

Tillich, P., 1952, The courage to be, Yale Nota Bene, New Haven, CT.

Tyson, P., 2001, The Hippocratic Oath Today, NOVA Posted 03.27.01, viewed 17 March 2018, from http://www.pbs.org/wgbh/nova/body/hippocratic-oathtoday.html

Van der Walt, J.P., 2016, 'A key to overcome challenges in ministry training "Diversification in training models"', in M. Nsidoo (ed.), Contested issues in training ministers in South Africa, pp. 155-169, SUN Press, Stellenbosch. 